\title{
TINDAKAN PENGHINAAN YANG MENGHAMBAT PROSES PERADILAN (CONTEMPT OF COURT) DALAM PENEGAKAN HUKUM DI INDONESIA
}

\author{
Muhammad Fadli (1) \\ muhammadfadli687@gmail.com $^{(1)}$ \\ Universitas Pendidikan Nasional
}

\begin{abstract}
The trial process in Indonesia recognizes the principle of open trial and is open to the public, the trial process of decency cases and children as defendants. With this principle, anyone can visit, see and follow the trial. These acts of contempt of justice are actually avoided by new things. However, these actions have become increasingly frequent since the advent of freer reforms. Insult to the court is an act that must be considered in Indonesia, this is related to the court action against the trial process. Law enforcement against criminal acts against the judiciary has several components that are in accordance with the justice system of justice which includes justice that starts from the police, court, prosecutors, and correctional institutions.
\end{abstract}

Keywords: Law Enforcement, Humiliation, Court

\section{ABSTRAK}

Proses persidangan di Indonesia mengenal asas persidangan terbuka dan dibuka untuk umum kecuali proses persidangan terhadap kasus kesusilaan dan anak sebagai terdakwa. Dengan adanya asas tersebut maka setiap orang dapat menghadiri, melihat dan mengikuti jalannya persidangan. Tindakan-tindakan penghinaan terhadap peradilan ini sebenanya bukanlah hal baru. Namun berbagai tindakan tersebut makin sering terjadi semenjak bergulirnya era reformasi yang lebih bebas. Penghinaan terhadap pengadilan merupakan suatu tindakan yang harus diperhatikan di Indonesia, hal ini dikarenakan tindak pidana penghinaan terhadap peradilan dapat menghambat proses persidangan. Penegakan hukum terhadap terjadinya tindak pidana penghinaan terhadap peradilan memiliki beberapa komponen sesuai dengan sistem peradilan pidana yaitu penanganan yang dimulai dari aparat kepolisian, pengadilan, kejaksaan, dan lembaga pemasyarakatan.

Kata Kunci: Penegakan Hukum, Penghinaan, Pengadilan

\section{PENDAHULUAN}

Manusia sebagai makhluk sosial tentu saja tidak dapat memisahkan hidupnya dengan manusia lain. Bermacam - macam bentuk kebudayaan, tatanan hidup, dan sistem kemasyarakatan terbentuk karena interaksi dan benturan kepentingan antara satu manusia dengan manusia lainnya. Kehidupan berkelompok, manusia membentuk sebuah aturan-aturan untuk menciptakan keteraturan dan mencegah atau mengatasi tindakan yang merugikan manusia sehingga tercipta kehidupan masyarakat yang aman dan tentram. 
Indonesia merupakan Negara hukum seperti yang tercantum dalam Pasal 1 ayat (3) Undang-Undang Dasar 1945 Perubahan ke-4. Ketentuan pasal tersebut menjelaskan dengan tegas bahwa Indonesia merupakan negara hukum. Indonesia sebagai negara hukum memiliki lembaga peradilan yang bertugas untuk melindungi kepentingan hukum dan sekaligus menjalankan perintah yang diatur dalam undang-undang. Lembaga peradilan di Indonesia, sesuai dengan kewenangan yang telah di berikan oleh Undang-undang No 4 Tahun 2004 terdiri atas Mahkamah Konstitusi, Mahkamah Agung, Peradilan Umum, Peradilan Militer, Peradilan Agama, Peradilan Tata Usaha Negara dan Peradilan Tindak Pidana Korupsi.

Lembaga peradilan merupakan lembaga yang melakukan suatu proses untuk mencari keadilan yang berisikan hak dan kewajiban menyelenggarakan peradilan guna penegakan hukum dan keadilan'. Seiring dengan perubahan dan perkembangan dunia, peranan pengadilan menjadi penting dalam hal sebagai tertib hukum. Pengadilan sebagai salah satu prantara dari hukum modern yang telah mendapatkan kepercayaan dari masyarakat.

Budaya hukum yang timbul di dalam masyarakat, melalui hukum positif yang telah diundangkan, telah tercipta suatu pandangan umum bahwa lembaga peradilan merupakan suatu mekanisme yang disediakan negara untuk menyelesaikan suatu sengketa, Menurut Satjipto Rahardjo, alasan yang mendorong masyarakat menyelesaikan sengketanya ke pengadilan adalah:

1. Kepercayaan, bahwa ditempat itu mereka akan memperoleh keadilan seperti mereka kehendaki.

2. Kepercayaan bahwa lembaga peradilan merupakan lembaga yang mengekspresikan nilai-nilai kejujuran, mentalitas yang tidak korup dan nilai-nilai utama lainnya.

3. Waktu dan biaya yang mereka keluarkan tidak sia-sia.

4. Pengadilan merupakan tempat bagi orang untuk benar-benar memperoleh perlindungan hukum².

${ }^{1}$ Adi Sulistiyono, 2011, Krisis Lembaga Peradilan di Indonesia, LPP UNS dan UNS Press, Surakarta,h.35.

2 Satjipto Rahadjo, 2009, Negara Hukum Yang Membahagiakan Rakyatnya, Genta Publishing, Yogyakarta, h.67. 
Perkembangan social yang dapat mempengaruhi pola-pola pikir dalam halnya tindakan manusia, sebagai salah satu contohnya adalah perbuatan yang dianggap merendahkan dan merongrong harkat, martabat dan kehormatan terhadap peradilan dunia, perbuatan tersebut disebut sebagai tindak pidana Contempt of Court ${ }^{3}$. Di Indonesia istilah Contempt of Court baru dikenal pada tahun 1985 dengan diundangkannya UndangUndang Nomor 14 Tahun 1985 tentang Mahkamah Agung. Dalam Penjelasan Umum butir 4, yang disebutkan :

"Untuk dapat lebih menjamin terciptanya suasana yang sebaik baiknya bagi penyelenggaraan peradilan guna menegakkan hukum dan keadilan berdasarkan Pancasila, maka perlu dibuat suatu undang-undang yang mengatur penindakan terhadap perbuatan, tingkah laku, sikap dan atau ucapan yang dapat merendahkan dan merongrong kewibawaan, martabat dan kehormatan suatu badan peradilan yang dikenal sebagai Contempt of Court."

Pengertian yang dijelaskan diatas dapat dipahami bahwa penjelasan tertuju pada wibawa, martabat, dan kehormatan badan peradilan. Namun karena suatu lembaga adalah suatu yang abstrak, maka ketiga hal tersebut yaitu wibawa, martabat dan kehormatan tertuju pada:

a. Manusianya yang menggerakkan lembaga tersebut;

b. Hasil buatan lembaga tersebut;

C. Proses kegiatan dari lembaga tersebut ${ }^{4}$.

Oleh karena itu, apabila terdapat perbuatan-perbuatan atau tindak pidana yang ditujukan terhadap tiga hal tersebut di atas, maka perbuatan tersebut dapat dikategorikan sebagai tindak pidana penghinaan terhadap proses peradilan (Contempt of Court) ${ }^{5}$.

Pengertian Contempt of Court dari Black's Law Dictionary disebutkan bahwa Contempt of Court adalah setiap perbuatan yang dapat dianggap mempermalukan, menghalangi atau merintangi tugas dari suatu proses peradilan ataupun segala tindakan yang dapat mengurangi kewibawaannya atau martabatnya ${ }^{6}$. Perbuatan itu dilakukan seseorang dengan sengaja menentang atau melanggar kewibawaannya atau menggagalkan tugas dari suatu proses peradilan yang dilakukan oleh seseorang dengan menjadi

3 Kuat Pudji Prayitno, 2005, Prospek Pengaturan Contempt of Court dan Permasalahannya, Fakultas Hukum Universitas Jenderal Soedirman, Purwokerto, h.45.

4 Ibid,h.8.

5 Ibid,h.12.

6 Bagir Manan, 2013, Memulihkan Peradilan yang Berwibawa dan Dihormati, Ikatan Hakim Indonesia, Jakarta,h.70. 
pihak dalam perkara yang diadili dengan sengaja tidak mematuhi perintah pengadilan yang sah. Istilah Contempt of Court berasal dari kata Contempt yang artinya menghina atau penghinaan dan Court artinya pengadilan, sehingga istilah Contempt of Court diterjemahkan sebagai suatu tindakan yang dimaksudkan untuk menghina badan pengadilan ${ }^{7}$. Menurut Oemar Senoadji bahwa Contempt of Court ditujukan terhadap ataupun berhadapan dengan jalannya proses peradilan "Administration of Justice", (recht pleging). Dalam suatu proses perkara pidana, baik tingkat penyidikan, penuntutan, maupun di tingkat persidangan pengadilan, kerap kali terjadi perbuatan-perbuatan yang menghalang-halangi dan merintangi proses peradilan pidana, yang dikenal dengan "obstruction of justice". Sedangkan dalam sidang perkara pidana dipengadilan, sering terjadi perbuatan-perbuatan yang dapat merendahkan wibawa hakim dan meruntuhkan martabat pengadilan. Perbuatan seperti itu, dikenal dengan istilah "contempt of court".

Perbuatan-perbuatan obstruction of justice tersebut ada yang terjadi pada fase proses pra ajudikasi dan fase ajudikasi pada proses peradilan pidana. Sedangkan perbuatan contempt of court sering terjadi pada fase ajudikasi, dimana dalam proses persidangan di pengadilan, baik sebelum persidangan berjalan maupun pada pasca proses persidangan. Perbuatan yang merendahkan kehormatan, wibawa dan martabat pengadilan atau mengganggu jalannya persidangan, dapat berupa membuat keributan, bersorak-sorak dan bertepuk-tepuk tangan di ruang sidang, dapat dikategorikan sebagai perbuatan criminal contempt ${ }^{9}$.

Tindakan-tindakan tersebut merupakan tindakan melawan hukum yang dapat dianggap mempermalukan, menghalangi atau merintangi tugas peradilan dari badan-badan pengadilan ataupun segala tindakan yang dapat mengurangi kewibawaannya atau martabatnya. Lembaga peradilan, hakim dan putusannya, harus bermartabat, berwibawa, dihargai, dihormati dan dipatuhi oleh semua pihak dalam suatu proses peradilan. Perlunya mengangkat kehormatan pengadilan, hakim dan hasil putusannya, bertujuan untuk memenuhi harapan masyarakat dalam mendapatkan suatu

7 Ibid,h.73.

8 Seno Adji, Oemar dan Indriyanto Seno Adji, 2007, Peradilan Bebas \& Contempt of Court, Diadit Media, Jakarta,h.45.

9 lbid, h.48. 
keadilan (Justitiabelance). Dengan dimikian agar penyelenggaraan suatu proses peradilan dan sidang dipengadilan dilaksanakan dengan baik, aman, nyaman dan tanpa gangguan dari pihak manapun, agar masyarakat terlayani secara baik, tepat waktu dan segera mendapatkan kepastian hukum. Berdasarkan latar belakang penelitian di atas, maka dapat dirumuskan permasalahan sebagai berikut: Bagaimana penegakan hukum terhadap tindak pidana penghinaan terhadap peradilan (Contempt Of Court)?

\section{METODE PENELITIAN}

jenis penelitian Normatif atau kepustakaan ini merupakan pemecahan masalah yang didasarkan pada literatur serta peraturan perundangundangan yang berkaitan dengan penegakan hukum terhadap tindak pidana penghinaan terhadap peradilan (Contempt Of Court). Bahan hukum terdiri dari bahan hukum primer yaitu bahan hukum yang mengikat seperti peraturan perundang-undangan yang berhubungan dengan penelitian ini seperti Undang-undang Dasar Negara Republik Indonesia Tahun 1945, Undang-undang Nomor 14 Tahun 1985 Tentang Mahkamah Agung, Undang-undang Nomor 48 Tahun 2009 Tentang Kekuasaan Kehakiman, bahan hukum sekunder dan bahan hukum tersier.Permasalahan mengenai penegakan hukum terhadap tindak pidana penghinaan terhadap peradilan (Contempt Of Court) dieksplanasikan secara jelas, kemudian dianalisis secara kualitatif untuk menggambarkan permasalahan yang dibahas.

\section{HASIL PENELITIAN DAN PEMBAHASAN}

\section{Penegakan Hukum Terhadap Tindak Pidana Penghinaan Terhadap Peradilan (Contempt Of Court)}

Penegakan hukum dalam kehidupan ketatanegaraan dijalankan oleh pemerintah (executive organ) dan oleh pengadilan (judicial organ) ${ }^{10}$. Kedua lembaga negara tersebut menjalankan fungsi penegakan hukum dengan cara yang berbeda. Pemerintah menjalankan fungsi penegakan hukum dengan cara aktif agar semua warga negara berperilaku sesuai dengan aturan hukum, sementara pengadilan menjalankan fungsi penegakan hukum

10 Barda Nawawi Arief, 2011, Masalah Penegakan Hukum dan Kebijakan penanggulangan Kejahatan, Aditya Bakti, Bandung, h.45. 
dengan cara pasif, menunggu orang mengajukan sengketa hukum (legal dispute) ke pengadilan untuk memperoleh putusan hukum (verdict vonis) ${ }^{11}$. Aturan merupakan salah satu unsur dalam penegakan hukum, selain penataan hukum, pelaksanaan hukum, dan penindakan hukum. Berbicara mengenai penegakan hukum secara luas dapat diartikan sebagai kegiatan untuk melaksanakan, menerapkan, serta melakukan tindakan hukum terhadap setiap pelanggaran atau penyimpangan hukum yang dilakukan oleh subjek hukum melalui prosedur peradilan. Adapun dalam arti sempit penegakan hukum itu menyangkut tindakan penegakan terhadap setiap pelanggaran atau penyimpangan terhadap peraturan perundang-undangan. Terdapat unsur-unsur dalam penegakan hukum yaitu penataan hukum, pelaksanaan hukum, penindakan hukum, dan penyelesaian sengketa.

Proses persidangan di Indonesia mengenal asas persidangan terbuka dan dibuka untuk umum kecuali proses persidangan terhadap kasus kesusilaan dan anak sebagai terdakwa, sebagaimana telah diatur dalam Pasal 153 ayat (3) KUHAP jo. Pasal 13 ayat (1) Undang-undang Nomor 48 Tahun 2009 tentang Kekuasaan Kehakiman:

1. Semua sidang pemeriksaan pengadilan adalah terbuka untuk umum, kecuali

2. undang-undang menentukan lain,

3. Putusan pengadilan hanya sah dan mempunyai kekuatan hukum apabila diucapkan dalam sidang terbuka untuk umum.

4. Tidak dipenuhinya ketentuan sebagaimana dimaksud pada ayat (1) dan ayat (2) mengakibatkan putusan batal demi hukum.

Dengan dasar hukum tersebut maka setiap orang dapat menghadiri, melihat dan mengikuti jalannya proses persidangan. Pemeriksaan sidang Pengadilan yang terbuka untuk umum kadang kala mengundang perhatian masyarakat apalagi jika kasus tersebut melibatkan pejabat negara, pengadilan terlihat sangat ramai dipenuhi oleh orang-orang yang ingin menyaksikan persidangan tersebut, hanya saja sering dijumpai banyak pengunjung persidangan baik itu para pihak yang terlibat langsung dalam perkara tersebut maupun pengunjung terkadang dapat membuat tindakan yang tidak menghargai jalannya persidangan.

Terdapat 5 (lima) bentuk yang termasuk dalam pengertian penghinaan

\footnotetext{
${ }^{11} \mathrm{Ibid}, \mathrm{h} .55$.
} 
terhadap pengadilan (Contempt Of Court) antara lain:

a. Berperilaku tercela dan tidak pantas di Pengadilan (Misbehaving in Court). Misbehaving in court adalah tiap perbuatan isyarat (gesture) ataupun kata-kata yang merupakan rintangan ataupun mengadakan obstruksi terhadap aliran (flow) normal dan harmonis dari proses di persidangan. Contempt of Court yang terjadi karena adanya misbehaving in court memenuhi dua fungsi yang berlainan. Pertama,secara meniadakan, mengadakan eliminasi terhadap kekisruhan (nuisance) dengan mengadakan restorasi ketertiban dan menjamin fungsionering yang lancar dari pemeriksaan judisial. Kedua, fungsinya lebuh bersifat judicial represif untuk dapat menghukum dan atau memidanakan orang yang melakukan perbuatan yang tidak patut di puji dan harus ditegur;

b. Tidak mentaati perintah-perintah pengadilan (Disobeying Court Orders). Disobeying court order suatu perbuatan yang tidak memenuhi perintah pengadilan ataupun yang merendahkan otoritas , wibawa atau keadilan dari pengadilan. Unsur ini umumnya terdiri atas perbuatan dari pihak lain dari pada yang dimintakan, dituntut dari padannya, ataupun tidak melakukan perbuatan apa yang diperintahkan atau diminta oleh proses tidak dalm kernagka " Contempt of Court " khususnya yang mengenai bentuk disobeying court's order terdapat dalam KUHP suatu ketentuan pidana yang mungkin dapat dikategorisasi sebagai suatu tak pematuahan terhadap perintah perngadilan;

c. Menyerang integritas dan impartialitas pengadilan (Scandalising the Court). Scancalizing the court adalah pernyataan di luar pengadilan dan sering merupakan publikasi yang mengandung suatu lapangan yang luas mengenai situasi. Scandalizing the court merupakan tipe lain dari misbehaving in court atupun disrupsi dalam pengadilan. Hal demikian terjadi, apabila ia merupakan hasil dari bahasa yang merupakan penghinaan ringan terhadap pengadilan ataupun serangan terhadap impartialitas selama proses berjalan. Scancalizing the court meliputi pernyataan yang menjengkelkan, mengandung kata-kata penyalahguanaan ataupun ucapan yang mengandung penghinaan. Semua perbuatan tersebut ditujukan 
terhadap hakim ataupun pernyataan yang meragukan impartialitas dari hakim tersebut. Tujuan dari tipe scancalizing the court adalah untuk mengadakan perlindungan terhadap reputasi peradilan, obyektifitas ataupun kejujuran dari peradilan itu sendiri. Selain itu, scancalizing the court, juga bermaksud untuk mengadakan promosi, menganjurkan suatu kepercayaan umum pada berbagai institusi judisial;

d. Menghalangi jalannya penyelenggaraan peradilan (Obstructing Justice). Obstruction justice merupakan suatu perbuatan yang ditujukan terhadap, ataupun yang mempunyai efek memutarbalikan, mengacaukan fungsi normal dan kelancaran suatu proses judisial. Obstruction justice, apabila dilihat sebagai suatu perbuatan adlah ebagai pengurangan kebaikan, fairness, ataupun efficiency dari suatu proses. Sedangkan disruption lebih merupakan suatu tantangan langsung dan fisik;

e. Perbuatan-perbuatan penghinaan terhadap pengadilan dilakukan dengan cara pemberitahuan/publikasi (Sub-Judice Rule). Sub judice rule adalah suatu usaha berupa perbuatan, atau sikap yang ditujkan ataupun pernyataan secara lisan apalagi secara tulisan, yang nantinya menjadi persoalan pers dan aspek hukumnya untuk dapat mempengaruhi suatu putusan yang akan dijatuhkan oleh hakim ${ }^{12}$.

Tindakan tersebut dikategorikan sebagai penghinaan terhadap Pengadilan (Contempt Of Court). Sementara itu, di dalam ketentuan Kitab Undang-undang Hukum Pidana (KUHP) yang berlaku saat ini terdapat beberapa pasal yang termasuk penghinaan terhadap pengadilan diantaranya:

"Pasal 207 KUHP

Barang siapa dengan sengaja di muka umum dengan lisan atau tulisan menghina suatu penguasa atau badan umum yang ada di Indonesia, diancam dengan pidana penjara paling lama satu tahun enam bulan atau pidana denda paling banyak empat ribu lima ratus rupiah."

"Pasal 217 KUHP

Barang siapa menimbulkan kegaduhan dalam sidang pengadilan

12 Seno Adji, Oemar dan Indriyanto Seno Adji, 2007, Peradilan Bebas \& Contempt of Court ,Diadit Media, Jakarta, h.89. 
atau di tempat di mana seorang pejabat sedang menjalankan tugasnya yang sah di muka umum, dan tidak pergi sesudah diperintah oleh atau atas nama penguasa yang berwenang, diancam dengan pidana penjara paling lama tiga minggu atau pidana denda paling banyak seribu delapan ratus rupiah."

"Pasal 224 KUHP

Barang siapa dipanggil sebagai saksi, ahli atau juru bahasa menurut undang-undang dengan sengaja tidak memenuhi kewajiban berdasarkan undang-undang yang harus dipenuhinya, diancam:

1. dalam perkara pidana, dengan pidana penjara paling lama sembilan bulan;

2. dalam perkara lain, dengan pidana penjara paling lama enam bulan."

Sistem peradilan pidana (criminal justice system) adalah sistem dalam suatu masyarakat untuk menaggulangi masalah kejahatan. Sistem peradilan pidana mempunyai komponen, yaitu kepolisian, kejaksaan, pengadilan, dan lembaga pemasyarakatan yang diharapkan dapat bekerja secara integratif sesuai dengan fungsi dan tugas masing-masing dalam mekanisme peradilan pidana. Peranan aparat penegak hukum sangat besar dalam upaya penanganan terjadinya tindak pidana penghinaan terhadap peradilan (contempt of court), sistem Peradilan Pidana adalah sistem dalam suatu masyarakat untuk menanggulangi kejahatan, dengan tujuan:

a. Mencegah masyarakat menjadi korban kejahatan;

b. Menyelesaikan kasus kejahatan yang terjadi sehingga masyarakat puas bahwa keadilan telah ditegakkan dan yang bersalah dipidana;

c. Mengusahakan mereka yang pernah melakukan kejahatan tidak mengulangi lagi kejahatannya. ${ }^{13}$

Sistem peradilan pidana pelaksanaan dan penyelenggaraan penegakan hukum pidana melibatkan badan-badan hukum yang masingmasing memiliki fungsi sendiri-sendiri, Badan-badan tersebut yaitu kepolisian, kejaksaan, pengadilan dan lembaga pemasyarakatan. Peranan

${ }^{13}$ Wahyu Wagiman, 2015, Contempt of Court Dalam Rancangan KUHP, Jakarta,h.78. 
aparat penegak hukum sangat besar dalam upaya penanganan terjadinya tindak pidana penghinaan terhadap peradilan (contempt of court) yaitu sebagai berikut:

1) Penanganan Oleh Aparat Kepolisian

Pihak kepolisian sebagai pengayom masyarakat sangat berperan penting dalam melakukan penertiban terhadap berbagai tindakan penghinaan terhadap peradilan. Kepolisian sebagai ujung tombak dalam penegakan hukum harus dapat bergerak cepat dan tanggap terhadap berbagai tindak pidana yang terjadi di wilayahnya karena tugas utama kepolisian adalah untuk menajga keamanan dan ketentraman msyarakat. Polisi harus mepunyai peran penting dalam hal melakukan penyelidikan terhadap tindak pidana penghinaan terhadap peradilan (contempt of court).

2) Penanganan Oleh Aparat Kejaksaan

Lembaga kejaksaan dalam sitem peradilan pidana yang terpadu merupakan salah satu subsistem. Undang-Undang terakhir yang mengtur tentang Kejaksaan adalah UU. No.5 Tahun 1991. dalam UU No. 5 Tahun 1991, diatur mengenai bagaimana lembaga kejaksaan dalam memerankan dirinya menjadi salah satu subsistem dari sistem peradilan pidana di Indonesia, kejaksaan merupakan lembaga pemerintah yang bertugas dalam melakukan penuntutan. Dalam kaitannya dengan tindak pidana penghinaan terhadap peradilan (Contempt of Court) jaksa berperan dalam melakukan penuntutan di depan pengadilan.

3) Penanganan Oleh Aparat Peradilan

Sistem peradilan pidana dalam arti luas identik dengan sistem kekuasaan kehakiman yang pada hakikatnya merupakan sistem penegakan hukum. Bekerjanya sistem peradilan pidana atau sistem kekuasaan kehakiman yang dikenal dengan istilah "Criminal Justice System" melalui tahap yang cukup panjang, lembaga peradilan bertugas untuk memberikan putusan yang adil terhadap setiap kasus yang mereka tangani baik perdata maupun pidana, Sistem peradilan pidana (Criminal Justice System) secara singkat dapat diartikan sebagai suatu sistem dalam masyarakat untuk menanggulangi kejahatan agar hal tersebut berada dalam batas-batas toleransi masyarakat. Institusi peradilan merupakan pihak yang berperan memutuskan hukuman yang akan dijatuhkan terhadap suatu kasus yang terjadi, hakim sebagai pihak yang intelektual sangat beperan penting dalam 
memutuskan suatu perkara, karena dalam memutuskan suatu perkara, hakim harus berpegang kepada peraturan perundang-undangan yang berlaku selain daripada keyakinan hakim itu sendiri. Putusan hakim adalah suatu pernyataan hakim, sebagai pejabat Negara yang diberi wewenang, dimana putusan tersebut diucapkan dipersidangan yang bertujuan untuk menyelesaikan suatu perkara.

4) Penanganan Oleh Lembaga Pemasyarakatan

Penegakan hukum pidana sebagai suatu sistem harus merupakan suatu kesatuan aparat penegak hukum yang bertugas menindak para pelanggar hukum. Pemasyarakatan merupakan bagian yang paling akhir dari sistem pemidanaan dalam tata atau sistem peradilan pidana. Sebagai sebuah tahapan pemidanaan terakhir, sudah semestinya dalam tingkatan ini harus dapat diupayakan tercapainya tujuan pemidanaan. Dalam kaitannya dengan tindakan pelecehan terhadap peradilan, strategi pemasyrakatan dapat dilihat dalam kerangka suatu criminal justice system. Strategi pemasyarakatan dalam lembaga pemasyarakatan tidaklah berdiri sendiri, melainkan merupakan suatu rangkaian lanjutan dalam pelaksanaan penegakan hukum yang panjang. Pada prinsipnya lembaga pemasyarakatan bertujuan agar nantinya terdakwa yang telah diputus oleh peradilan bersalah, apabila ia telah dikembalikan kemasyarakat dapat kembali seperti sebelum terdakwa menjalani proses hukuman di lembaga pemasyarakatan.

Penulis berpendapat bahwa ada beberapa factor penyebab terjadinya tindak pidana penghinaan terhadap peradilan, yaitu:

a. Kurangnya kepercayaan publik terhadap peradilan dan hakim;

b. Belum adanya suatu aturan yang baku tentang sejauh mana pebuatan yang dapat dikategorikan sebagai suatu tindakan penghinaan terhadap pengadilan;

c. Kurangnya kesadaran masyarakat akan pentingnya budaya hukum;

d. Masyarakat salah mengartikan makna dari reformasi.

Muladi menyampaikan bahwa dalam usaha penanggulangan kejahatan, politik kriminal membagi dalam berbagai bentuk, yaitu :

1. Bentuk yang bersifat represif yang menggunakan sarana penal, yang sering disebut sebagai peradilan pidana (criminal justice 
system) secara luas mencakup proses kriminalisasi;

2. Usaha-usaha tanpa menggunakan sarana penal (Prevention Without Punishment);

3. Usaha-usaha pembentukan opini masyarakat tentang kejahatan dan sosialisasi hukum melalui media massa ${ }^{14}$.

Upaya penanggulangan kejahatan lewat jalur "penal" lebih kepada sifat represif (penindasan/penumpasan) sesudah kejahatan terjadi, sedangkan jalur "non penal" lebih kepada sifat preventif (pencegahan/penangkalan) sebelum kejahtan terjadi. Dikarenakan upaya penanggulangan kejahatan lewat jalur non penal lebih bersifat tindakan pencegahan sebelum terjadinya kejahatan, maka sasaran utamanya adalah menangani fakto-faktor kondusif penyebab terjadinya tindak pidana penghinaan terhadap peradilan (contempt of court), faktor-faktor penyebab terjadinya tindak pidana penghinaan terhadap peradilan yaitu;

1. Kurang sempurnanya peraturan perundang-undangan yang mengatur tindak pidana penghinaan terhadap peradilan;

2. Kurangnya kepercayaan publik terhadap dunia peradilan sebagai benteng terakhir pencari keadilan;

3. Rendahnya budaya hukum masyarakat Indonesia yang berimplikasi terhadap penegakan hukum.

Dengan demikian, dalam upaya merumuskan kebijakan hukum pidana untuk menanggulangi terjadinya tindak pidana penghinaan terhadap peradilan secara konseptual dapat dilakukan melalui:

\section{Upaya Preventif}

Upaya preventif adalah upaya yang ditujukan untuk menghilangkan kesempatan terjadinya kejahatan contempt of court terhadap hakim merupakan upaya awal yang dilakukan oleh aparat penegak hukum. Pihak Pengadilan Negeri bekerja sama dengan kepolisian dalam melakukan pengawasan pada saat berlangsungnya proses persidangan, pengawasan paling utama pada saat mengadili perkara pembunuhan dan penganiayaan, karena pada kasus seperti ini paling sering terjadi kejahatan contempt of court. Disini pihak kepolisian peranannya sebagai petugas keamanan, sebagaimana telah diberikan kewenangan untuk mencegah terjadinya kejahatan, selain itu adapun bentuk pencegahan dari segi internalnya

\footnotetext{
${ }^{14}$ Muladi, 2012, Bunga Rampai Hukum Pidana, Bandung, h.90.
} 
adalah sebagai berikut;

a. Membenahi oknum-oknum di pengadilan, pembinaan sikap dan mental secara terpadu dan berkesinambungan sehingga meningkatkan integritas ilmu hukumnya;

b. Harus melakukan pelayanan maksimal kepada pencari keadilan;

c. Hakim harus profesional dalam melaksanakan tugasnya;

d. Putusan pengadilan harus lebih berkualitas, harus mencerminkan kepastian hukum, keadilan, dan kemanfaatan.

Lebih lanjut adapun upaya pencegahan dari segi eksternal adalah sebagai berikut:

a. Harus ada kesadaran hukum masyarakat, agar bukan menang atau kalah yang dicari akan tetapi keadilan;

b. Masyarakat sebaiknya berpikir lebih objektif menilai hakim.

\section{Upaya Represif}

Upaya represif ini merupakan upaya penanggulangan kejahatan contempt of court yang telah terjadi, artinya sudah atau telah terdapat korban dalam kejahatan ini. Oleh karena itu dalam upaya ini perlu dilakukan suatu tindakan yang efektif dalam memberikan perlindungan terhadap hakim sebagai korban kejahatan contempt of court. Dengan mengadakan Undang-undang yang mengatur tentang contempt of court dan menerapkan sanksi hukum yang tegas kepada pelaku kejahatan merupakan suatu bentuk perlindungan hukum kepada majelis hakim atau pengadilan yang menjadi korban kejahatan contempt of court dalam hal ini penghinaan (cacian, hujatan kata-kata yang tidak etis) terhadap hakim atau pengadilan. Tetapi bukan hanya terbatas pada dihukumnya pelaku, namun juga akibat-akibat yang diterimanya sehingga memberikan efek jerah kepada pelaku kejahatan dan mewujudkan ketertiban dalam berlangsungnya proses persidangan.

\section{KESIMPULAN}

Kesimpulan tersebut akan diuraikan lebih lanjut dalam poin berikut: Upaya penegakan hukum terhadap terjadinya tindak pidana penghinaan terhadap pengadilan (Contempt Of Court) memiliki beberapa komponen sesuai dengan sistem peradilan pidana yaitu penanganan yang dimulai dari aparat kepolisian, pengadilan, kejaksaan, dan lembaga pemasyarakatan. 
penanggulangan terjadinya tindak pidana penghinaan terhadap pengadilan dapat dilakukan melalui sarana-sarana yaitu: Upaya Preventif adalah upaya yang ditujukan untuk menghilangkan kesempatan terjadinya kejahatan contempt of court; dan upaya Represif ini merupakan upaya penanggulangan kejahatan contempt of court yang telah terjadi.

Kesadaran masyarakat akan pentingnya hukum perlu ditingkatkan. Peningkatan kesadaran hukum masyarakat merupakan aspek penting dalam proses penegakan hukum (law enforcement). Tanpa adanya budaya hukum yang baik dari masyarakat (legal culture), perundang-undangan yang baik (legal substance) dan aparat penegak hukum yang profesional (legal structure) tidak dapat befungsi dengan baik. Peningkatan kesadaran masyarakat merupakan salah satu bentuk upaya pencegahan terhadap terjadinya tindak pidana penghinaan terhadap peradilan (Contempt Of Court).

\section{DAFTAR PUSTAKA}

Buku:

Adji,Seno, Oemar dan Indriyanto Seno Adji, 2007, Peradilan Bebas \& Contempt of Court, Diadit Media, Jakarta.

Barda Nawawi Arief, 2011, Masalah Penegakan Hukum dan Kebijakan penanggulangan Kejahatan, Aditya Bakti, Bandung.

Manan,Bagir, 2013, Memulihkan Peradilan yang Berwibawa dan Dihormati, Ikatan Hakim Indonesia, Jakarta.

Muladi, 2012, Bunga Rampai Hukum Pidana, Bandung.

Rahadjo,Satjipto, 2009, Negara Hukum Yang Membahagiakan Rakyatnya, Genta Publishing, Yogyakarta.

Sulistiyono,Adi, 2011, Krisis Lembaga Peradilan di Indonesia, LPP UNS dan UNS Press, Surakarta.

Prayitno,Kuat Pudji, 2005, Prospek Pengaturan Contempt of Court dan Permasalahannya, Fakultas Hukum Universitas Jenderal Soedirman, Purwokerto.

Wahyu Wagiman, 2015, Contempt of Court Dalam Rancangan KUHP, Jakarta.

\section{Peraturan Perundang-Undangan}

Undang-Undang Dasar Negara Republik Indonesia Tahun 1945

Undang-Undang Nomor 14 Tahun 1985 Tentang Mahkamah Agung

Undang-Undang Nomor 48 Tahun 2009 Tentang Kekuasaan Kehakiman 